\title{
Foreign Impressions of Neapolitan Art in the Sixteenth Century
}

\section{BEATE STOCK}

Italy during the Renaissance: why, one might ask, would travellers visit the Kingdom or the City of Naples? Naples was not, at the time, a leading centre for the visual arts, as were Florence and later Rome. There was no artist of the stature of Bramante, Leonardo da Vinci, Michelangelo, or Raphael. Although Naples had many churches and convents, it was not a centre of pilgrimage. Pompeii and Herculaneum were not yet excavated and the "Grotta Azzurra" had not yet been rediscovered.

What then in Naples attracted the attention of sixteenth-century travellers? At the time under discussion, 1537 to 1600 , the Kingdom was governed by Spanish viceroys. To keep a close eye on the nobles, the viceroys compelled them to spend most of the year in the city, and this concentration of nobili - Naples was therefore called "La Gentile" - together with the splendid viceregal pageantry, created a colourful and lively social life that attracted foreigners.

The main reason many travellers visited Naples, however, was to study the remains of antiquity. In the surroundings of Naples were famous places like Pozzuoli, Baia, Cuma, the tunnel through the Posillipo, and the presumed tomb of Vergil. Travellers also observed various phenomena, such as the Cento Camerelle, the Lago di Agnano and the Grotta del Cane (where the experiment with the poor dog's losing consciousness when thrown in the grotto was repeated again and again to prove the emission of poisonous gas). These were the most important stations for the study of antiquity and natural phenomena known since the time of the Romans. They alone were important enough to bring travellers to Naples. But, as we shall see, there were other delights in the city, and generally speaking visitors showed awareness of these attractions.

A number of Renaissance travellers left written accounts of their visits to 
Naples. The eleven who make an appearance in this paper have been chosen because they show us, more or less distinctively, how they perceived the beauty of the city of Naples and its works of art. They write their accounts as personal experiences, although some of them depend heavily on others material. ${ }^{1}$ They come from various parts of Germany, England, the Netherlands, and Italy. There are no Spanish accounts, and the French, who would make at a later period the most valuable contribution to the category of travel literature on Italy, are not among sixteenth-century travellers to Naples who show an interest in the arts. ${ }^{2}$

Apart from the city of Naples, there were no intellectual or artistic centres of importance in the Kingdom. The interest in awesome or picturesque scenery had not yet arisen; few antique remains, besides those around Naples, were yet known to exist; and travel routes and accommodations away from the coast were also non-existent. Brigands, moreover, were a real danger. It is not surprising, all things considered, that few travellers visited towns in the regno other than Naples.

For most travellers, the visit to Naples was a natural extension of a visit to Rome - although Fynes Moryson was an exception. ${ }^{3}$ Moryson came to Naples before visiting Rome and other cities because he feared that the effects of the war between England and Spain might shortly make it impossible or at least more difficult and unpleasant for him to visit the Kingdom of Naples. As a Protestant travelling in a Catholic country, he had enough problems already. ${ }^{4}$ Samuel Kiechel, a young German Protestant, had similarly encountered difficulties related to his religious affiliation. ${ }^{5}$

While the journey south from Rome to Naples was mostly made overland and was not without danger, the danger of travelling south beyond Naples by land was such that, of our eleven travellers, only Thomas Hoby, who had come from Rome to Naples by ship, had the courage to venture it in 1550.6 Through Hoby's description of a part of this trip south, between Cosenza and Ajello, we can easily picture some of the danger involved:

Before we cum to St. Biasi wee ride throwghe a woode verie thick and jeopardous to passe called Bosco di Santo Mazzio, which hathe bine most famous for robberies and murtheres committed in yt, of all the rest within the realm. For the theves did not onlie robb in great companies within yt, but also yf they sawe a number ride so stronglie together that they thowght not themselves able to mak their part in good, they had emong the trees 
certain peices of artillarie to discharg at them, whiche were the deathe of manie a man. But now all the wood that was anie thing nige unto the high waye is burnt downe, and the trees remain full of coles, without eyther leaf or bowe abow them, and some lying upon the earthe half burnt. This was done by th'Emperor's commandment when he passed bye there. $^{7}$

The other three travellers of our group who went to Sicily and/or Malta (Kiechel, Gadenstedt, Duke August the Younger of BraunschweigWolfenbuttel) ${ }^{8}$ embarked at Naples. Even at sea there were dangers, as ships were constantly threatened not only by sudden storms but also by Turkish pirates. The city of Naples itself was, therefore, the principal attraction of their southward journey for most travellers venturing there.

The overall impression travellers in the sixteenth century had of the city of Naples and its situation was positive. But in comparison with some of the panegyrics of the centuries to come, their accounts are restrained and objective. Hoby best summarizes the reactions of the travellers in this period:

Naples is a verie beawtifull citie situated betwext
the seea and verie pleasant hilles, full of howses,
well fortified of late dayes with a strong wall that
th'Emperor hathe begonne abowt yt, replenisshed with
sumptious palaces, delicious gardines, and sundrie
devises of fountaynes abowt yt.

A detailed and delightful description of the gardens surrounding Naples, their grottos and fountains, their abundant flora and exotic fauna is found in Turler's book on the Kingdom of Naples. ${ }^{10}$ Hoby, on the other hand, in describing watering places and other natural phenomena, tells us principally of their use. The sudatorii near the Lago di Agnano, for example, are recommended for "good digestion and [to] resolve raw humors, they lighten the bodie and heale the inward partes, they drie upp fistles and woundes in the bodie, and are verie good against the gowte."11

In the sixteenth century the fortifications of a town were not only vital to its defence but also contributed to its beauty. All travellers, therefore, comment on the three main castles upon which the defence of the town mainly depended. The least important was the Castel dell'Ovo. The Castel S. Elmo, upon a rock, towering over and dominating the town, was the most 
impressive because of its position. But the strongest and most important castle was the Castel Nuovo by the sea.

Gadenstedt, who was in Italy from 1587 to 1589 and who left an unusually voluminous manuscript of 700 densely written pages of which more than 70 are dedicated to the Kingdom of Naples, ${ }^{12}$ tells us that the wall with its five solid towers was strong and that the Castel Nuovo was surrounded by a double moat. He also tells us that soldiers and craftsmen lived in the castle and that, on entering, one therefore got the impression of a small, separate town. 13

A very realistic description of the particularity of the castle's position is given by Razzi. ${ }^{14} \mathrm{He}$ shares the general conviction of its magnificent regal appearance, but then says that, although it is considered larger than Milan's castle, the latter is possibly stronger, because the town's palaces are too close to the Castel Nuovo and because it is dominated by the Castel S. Elmo on the hill. 15

Today the Castel Nuovo is famous for its triumphal arch, squeezed between two massive towers. The arch was constructed in 1454-67 to commemorate the conquest of Naples by Alfonso I. But, except Fichard and Turler, sixteenth-century travellers did not mention this remarkable quattrocento work. Fichard ${ }^{16}$ says that it was the most splendid arch he had seen, executed completely in marble. ${ }^{17}$ Turler refers to it as "a verie faire gate...made all of Marble."18

To enter the city it was necessary to pass through one of the city gates. Most travellers made mention of the Porta Capuana, through which the Emperor Charles V entered the town in November 1535 to celebrate the marriage of his daughter, Margherita d'Austria, to Alessandro Medici, Duke of Florence. Here again it is only Fichard, ${ }^{19}$ and Turler, whose account is derived from him, who give some idea of the gate's appearance. In Turler's English version, we read:

Upon the Gate...are manie Monuments to be seene... Beefore the Gate stoode the Images of Oceanus, and Tethis, and also in the streete in convenient places, were errected the Statues of Hercules, Athlas, Perpetuitie, Religion, and many other moe, whiche are set foorth in the Triumph of Naples. ${ }^{20}$ 
Renaissance et Réforme / 277

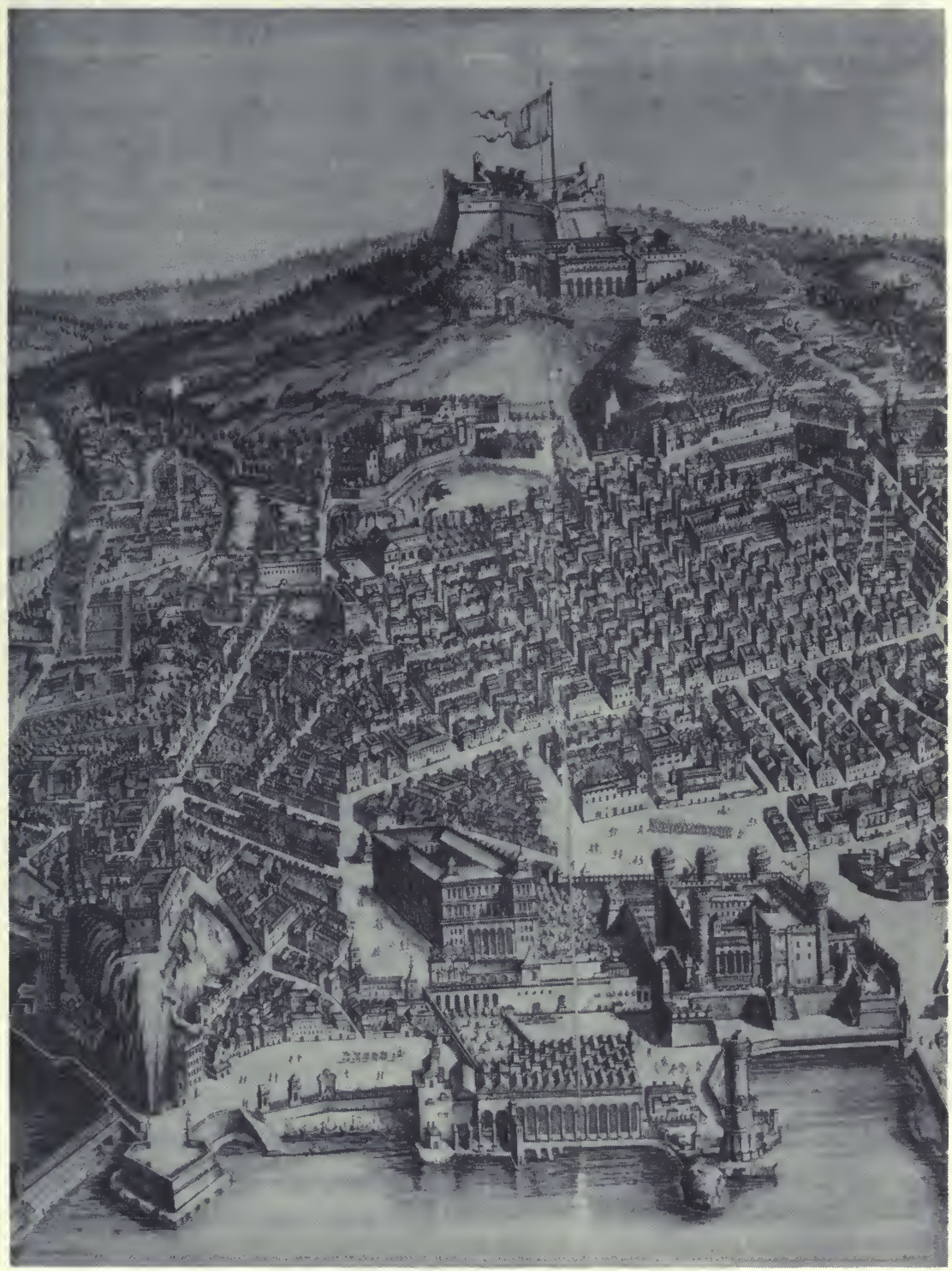

View of Naples (detail) by Bernhard Stopendaal, 1653. Fot. Soprintendenza ai Beni Artistici e Storici - Napoli) 
All travellers agree that the streets in Naples were relatively small, with the exception of three wide, straight, and long main streets. The most famous of the three was the Via Toledo, called after the Viceroy Pietro di Toledo, who had had it built. Fynes Moryson describes it as "A most faire and large street...the way whereof on both sides is raised with a faire and large pauement for men to walk vpon." ${ }^{21}$ Because most streets were so small, sedan chairs - so-called "seggioli di Napoli" - were used instead of coaches, a custom that pleased Moryson extraordinarily. After later observing similar chairs at Genua, he concluded "I think this fashion very conuenient."22

Although there were many palaces in the city, the travellers mentioned only a few. Hoby thinks that the palace of the Duke of Gravina, if it had been completed, could have compared with any other in Italy. ${ }^{23}$ Another stately palace frequently mentioned was the Palazzo Sanseverino. It belonged originally to the Prince of Salerno and was sold to the Jesuits who, while conserving great parts of the palace's façade, erected their church "Gesù Nuovo" there between 1584 and 1601, designed by P. Giuseppe Valeriani. Gadenstedt tells us how much the Jesuits had paid for the Palazzo $-45,000$ ducats - and that the old escutcheon had been replaced by a round plate on which the name of the Christ "Jesu" was written in golden letters. ${ }^{24}$ The new Royal Palace, which was already being replaced in 1600 by another new palace (today's Palazzo Reale), was sometimes noticed as well.

In the seventeenth and eighteenth centuries, travellers to Naples would praise, not individual palaces, but the agreeable ensemble created by the relative uniformity of architectural style. Such distinct observations cannot yet be found in the accounts of sixteenth-century travellers. Moryson, however, gives us an overview of the city's domestic architecture: "The houses of the City are foure roofes high...the building is of free stone, and sheweth antiquity: but the windowes are all couered with paper or linnen cloth; for glasse windowes are most rare in Italy."

One fact in particular strikes him, as it did many travellers coming from the north and accustomed to peaked roofs: the flat roofs of the Neapolitan houses, "so as they walke vpon them in the coole time of the night."25

Social life, in Italy in general, but especially in Naples where the climate is so favourable, is very much an outdoor activity and takes place not only on roof-tops but in markets and squares. Gadenstedt tells us that the square before the Castel Nuovo was the most distinguished and that it was surrounded by the residences of the rich and noble. ${ }^{26}$ This square was the centre of social life and entertainment, and Buchellius, ${ }^{27}$ a Dutchman who 
seems not to have been drawn to such entertainment, describes, not without disdain, its gay and fairlike atmosphere, the sale of scents and knick-knacks and the performance of comedies. ${ }^{28}$

Another important centre was the market place, "il Mercato." Turler says that the place is "Foursquare, and verye broade, and large, but not paued, in the midste wherof stande a paire of Gallowes, and a scaffold set vp for the nonce to put trespassers to death vpon: also a Chappell, rightouer againste whiche, is a Well with a very large Cesterne or Lauer." Turler also tells us: "In the Merket place are many Innes, but they bee of the meane and common sorte, and the greatest want in Naples, is of clenly and soote lodgings, although ther be an infinite number of Tauerns and vittling houses in it." 29

If sixteenth-century travellers chose to complain about Neapolitan inns, they agreed in praising the abundance of water and fountains. Fichard tells us that almost every house had its own fountain with pure water in abundance, an amenity no other Italian town could boast..$^{30}$ But their common approval of the abundance of fountains did not move the travellers to descriptions of individual examples. Whether this was so because none of the fountains at the time was striking enough, or because fountains were taken as a general embellishment of the city, is difficult to decide. All we are told is that at the end of the pier built into the sea there was a fountain with a marble basin bringing fresh water from the city. ${ }^{31}$

Naples is and has long been famous for her many richly-decorated Baroque churches. The situation was different, however, during the Renaissance, a time in which Naples was something of an artistic backwater. But Gadenstedt, who collected and compiled so much material on the Kingdom and the City of Naples, counted a total of 244 churches and convents in the city. Several, certainly, were of interest to travellers. ${ }^{32}$

The favourite, then as later, was the Certosa di S. Martino, a Carthusian monastery near the Castel S. Elmo, built in the fourteenth century. Towards the end of the sixteenth century, the Certosa underwent radical changes. It was enlarged and redecorated, and emerged finally as one of the most important works of art of the seventeenth-century Neapolitan Baroque.

Yet even before the changes, travellers considered the monastery splendid. Fichard was an exception: he was pleased only by the magnificent view he had from it. 33 But Pighius, the author of the well-known "Codex Pighianus," 34 who had lived in Italy several years and visited Naples twice, ${ }^{35}$ speaks in 1575 of a beautiful and sumptuous church and a large Carthusian 
monastery, a comment exactly repeated by Paul Hentzner at the end of the century. ${ }^{36}$

More substantial information comes from Gadenstedt, who mentions three well-built chapels each with a picture, well and skilfully painted: in the first, the story of St. Lawrence; in the second, the story of the three Magi; in the third, the story of Christ's birth. ${ }^{37}$

Duke August the Younger of Braunschweig-Wolfenbuttel was in Italy from 1598 to 1600 . His manuscript, like Gadenstedt's, is in the Library of Wolfenbuttel. Duke August scarcely ever writes a complete sentence: his comments are as short as Gadenstedt's descriptions are long. When he writes that in the Carthusian monastery near the Castel S. Elmo is a beautiful sacristy with inlaid work, one can surmise, therefore, that he must have been notably impressed. ${ }^{38}$

Most travellers in the sixteenth century - as in later centuries - showed a keen interest in history and therefore in tombs. They looked upon tombs not only as artifacts but as representations in which history came into life. The churches of S. Chiara and S. Giovanni a Carbonara were famous chiefly for their tombs. S. Chiara, founded about 1310 by Sancia di Maiorca, the wife of King Robert of Anjou, was from the beginning the church of the French kings and nobility and served also as burial place for most of the members of the Angevin royal family.

Although more than half of the travellers visited S. Chiara, only Gadenstedt gives us some description of the church and of two particular monuments. He tells us first that the church has a good height and width and that it is well built. He then speaks of King Robert's monument, describing the King sitting on a chair, holding a sceptre. But what most struck Gadenstedt was the symbolic representation of justice at the tomb of King Robert's eldest son, Charles of Calabria. He writes that there were carved in marble a wolf and a lamb eating together from a dish; and that from this it is to be understood that the ruler maintained justice so well that the poor were not repressed by the powerful. ${ }^{39}$

In S. Giovanni a Carbonara, Joan II, sister and successor of King Ladislas, erected a magnificent sepulchre for her brother. Of this monument we have not a description but a very distinct personal opinion. Turler, taking it erroneously for King Robert's monument, suddenly becomes very voluble in contesting the general view that this should be considered the most majestic work in all of Europe. He says: 
... the report goeth, that there is neuer a peece of worke to be found in all Europe, of greater maiestie then that is. Howbeit, if not faierer then this, yet in my opinion, match vnto it is that, wherein lyeth the bodie of William Croius and his Wife in Belgium or Dutchlande, not farre from Louane, at the Castle of Heffria. Likewise the Tumbe of Mauritius of Saxonie one of the Dukes Electours, at Friburge in Hermonduris, and that also wherein his Wyfe lieth at Vimaria, in Thuringe, and moreouer the same which is builded at Heidelburge, in the memorie of Duke Palatine, Duke Electour. Truly these 4 Tumbes which I haue nowe named, are the most principall of all that euer I sawe, ether in Italye, or France, or Germanie, or England, for, as for Spayne: I was never there. But amongst al that are seene in any of these aboue named Regions, made of Brasse or Copper, in my iudgement, theTumbe of Kinge Henrie the seuenth King of Englande, surpasseth the residew, whiche standeth in the Abbey of Westminster nigh to the Citie of London. $^{40}$

The principal convent of the Dominican Order in Southern Italy was S. Domenico Maggiore, built from 1289 to 1324. Just as the nobles' favourite church during the previous centuries had been S. Chiara, so during the Renaissance it was S. Domenico Maggiore. In this church as well the travellers could admire and record the magnificent funeral monuments in marble and alabaster. Gadenstedt mentions an artfully-made and gilded altar of nut wood said to have been very expensive.

Towards the end of the century, the convent had 130 friars and seems, according to Gadenstedt, to have had a good endowment. ${ }^{41}$ The church, too, had an impressive treasury, kept in the vestry. Razzi had seen it twice, and he noticed among other things: 25 silver lamps and another lamp which had cost 140 ducati, two censers, one gilded silver cup which was used by the nobles when they took communion, and various crucifixes, one of them crystal. Much appreciated were the hangings used at the funeral masses of the nobles. ${ }^{42}$ The convent had two hundred hangings, and on the main feast days, when the church was decorated with them, the friars "set it out with great advantage" as Lassels, almost a century later, still reports. ${ }^{43}$ Razzi also comments favourably on the vestments (not only rich but also clean) and the careful preparation for masses, nor does he overlook the many sacred 
relics or the magnificent stalls with inlaid work showing figures from the Old and New Testament. ${ }^{44}$

S. Domenico Maggiore was also famous for the fact that St Thomas Aquinas had stayed there, and it is believed that the representation of the crucified Christ had spoken to him: "Bene scripsisti de me, Thoma, quam ergo mercedem recipies?" ("Non aliam nisi te.") The Protestant Moryson is very critical of that legend and simply calls it a fraud and impostures of the friars, ${ }^{45}$ but Razzi, the Dominican friar, has naturally a very different approach. When he visited the convent, he was not only allowed to see the picture from below, but the "padre sagrestano" provided him with a ladder so he could climb up to see it more closely. After having touched and kissed it, he describes the crucifix, telling us that it was painted on wood, with a height of not more than "un braccio," the Virgin and St John on the sides, and, before them, smaller in size, St Dominic. "E sono figure alla antica," he comments.

The oldest known portrait of St Dominic, painted in the first half of the thirteenth century (the saint died in 1221), is also in this church. Razzi saw the "effigie naturale" as he calls it with the pointed cowl like the Capuchins. ${ }^{46}$

Naples' main church is S. Gennaro, also known as the "Duomo." It was erected through the initiative of Charles II of Anjou from 1294 to 1325, almost contemporaneously with S. Domenico Maggiore. Through the centuries, the cathedral underwent several substantial changes, and what we see today is quite different from what our travellers encountered. From the three who speak of S. Gennaro in our period, it is difficult to conceive a picture of the cathedral. No descriptions are given of the building as such, only an enumeration of its curiosities. Both Gadenstedt and Hentzner tell us that it is the burial place of the man who had first brought the "vinum graecum" to Italy ${ }^{47}$ There was also a picture of the Virgin Mary believed to have been done by St Luke. Gadenstedt claims to have seen it in the chapel built by the first Christians, probably referring to "S. Restituta," the oldest basilica in Naples, built in the fourth century and later incorporated into the Duomo as a side chapel. 48

In the presbytery under the main altar lies the body of the city's patron saint, S. Gennaro. His fame rests on the liquefaction of his blood (preserved in a small glass phial), which takes place on several occasions every year. Despite being the main church and the site of a miraculous transformation, S. Gennaro did not attract many visitors in the sixteenth century. Only after the new and most sumptuous chapel for the saint had been built (1608-37) 
in response to a vow made by the people of Naples to the saint during a terrible plague in 1526-29 did interest in the church rise considerably.

One of the most elegant creations of the Renaissance in Naples was the "Succorpo," a chapel under the presbytery of S. Gennaro which Cardinal Oliviero Carafa had had built from 1497 to 1506, but none of the travellers mentions it. Instead, Gadenstedt gives us a slightly piquant detail of a work carved in stone which was to be seen when one went down the stairs to the Succorpo. It showed a nude couple embracing and kissing. According to his account the sculpture was skilfully done and was shown to foreign visitors as evidence that they had visited that church. ${ }^{49}$

The church and convent of Monteoliveto, originally belonging to the order of Our Lady of Mount Olivet (today to the Congregation of S. Anna dei Lombardi), had become rich and influential through the protection of the House of Aragon, especially Alfonso II. Gadenstedt, who took them for Carthusians, tells us that there were seventy monks, all dressed in white and most of noble descent. 50 The church, containing the greatest number of high-quality Renaissance works in Naples, and the convent were begun in 1411.

Fichard is the first to comment on Monteoliveto. Although stating that it occupies a lovely site overlooking the city, is richly decorated, and with an interior completely faced with marble, he complains that the church is nevertheless narrow. ${ }^{51}$ Gadenstedt, for his part, describes the convent and church as well built and adorned with many monuments and several beautiful chapels. He mentions the Pietà, a group of impressively realistic figures in terracotta by Guido Manzoni (1492). It is believed that the figures in the group are modelled after members of the royal family of the Aragon; Joseph of Arimathea is regarded as a portrait of Ferdinand I and Nicodemus as Alfonso II. ${ }^{52}$ Gadenstedt thinks the composition is like one that is to be seen in Jerusalem, ${ }^{53}$ and Moryson, normally not easily impressed, writes:

In the most faire Church of the Monkes of Saint Oliuet, the Images of Ferdinand the first, and Alphonso the second, are so liuely engrauen, and doe so artificially represent them, as well in the bed dying, as vpon their knees praying, with the mourning of the by-standers, (the horror of Religion being increased with lampes continually burning, as my selfe by chance passing by this Chappel, thought I had fallen among liuing Princes, not dead Images; and perhaps I haue seene a 
more sumptuous monument, but a more beautifull did I never see. ${ }^{4}$

S. Caterina a Formello is the most recent and modern creation of all the churches mentioned so far. It was begun only in 1519 and built after the design of the Florentine architect Romolo Balsimelli. When Fichard was in Naples in 1537, it was still under construction, and it is understandable that he did not visit it, but neither did later travellers; even in the seventeenth and eighteenth centuries it was never a church popular with visitors.

Among our travellers, Friar Serafino Razzi was the only one to visit S. Caterina. He lodged there during his visit to Naples and gives us the most coherent picture and general appraisal of a convent, indeed of any architectural setting in Naples, of all our travellers. He writes:

And in my judgement this is the most beautiful convent, the most orderly, and the most comfortable which our order has nowadays in Naples. The church is beautiful. There are two main cloisters; one of them has about fifty orange trees which grace it throughout the year with their green foliage. The dormitories with about sixty cells are cross-vaulted upstairs and downstairs; it is most beautiful. The library holds forty benches with book-cases, i.e. twenty at each side, they are all covered with cloth and blue curtains, so that the dust will not ruin the books, and the walls are painted with figures in terra verde. In this magnificent convent are twelve to sixteen large and regal guest-rooms, with glass windows, with airy loggias, and with very beautiful, elaborate pavements. The hospice and the infirmary are comfortable, and the rooms well equipped. And the lavatory has basins all in white marble. 55

Looking at the descriptions of churches, we notice that the words most often used are beautiful, fair, magnificent, splendid, sumptuous, precious, skilfully done. When we note as well the frequent reference to the material used, especially marble and alabaster which attracted the Northerners most, and the descriptions of church treasures and the crown jewels which could be seen in the Castel Nuovo, ${ }^{56}$ it is very clear that travellers were mostly concerned with rich appearances - whether in churches, palaces or any other works of art. Churches and convents or buildings belonging to them had to be magnificent, splendid, and precious, not only to express piety and to elevate the spirit of the visitor, but to impress potential benefactors. Kiechel 
remarks in reference to the church and hospital of S. Annunziata that they had to have stately entrances in order to receive many donations. ${ }^{57}$

Travellers in the sixteenth century were not concerned with questions of current architectural theory. They were not yet concerned explicitly with proportions, regularity, symmetry, or order of columns. They did not distinguish various architectural styles nor did they pass judgement on the gothic, a word that was soon to be used to mark everything that seemed tasteless, unreasonable, or out of fashion.

We can determine more particularly, nevertheless, what the travellers expected from the buildings they visited, as when Fichard says in 1537 that the churches are narrow and "mediocriter splendidae,"58 and when Gadenstedt states in 1594 that S. Chiara is a "grosse hoche weitte and wollgebauete Kirche." 59 Churches, therefore, had to be large, spacious, and richly decorated, and one can expand this statement almost to architecture in general. Razzi expresses this and also the idea of regularity when he says the convent of S. Caterina a Formello was not only most beautiful and contained "logie ariose" but was also "il piu ordinato." 60 Similarly, there was no interest in architects or any other artists as persons. Only one name is given by Razzi. He tells us that the painting of the "Innocenti" in S. Caterina a Formello was done by Matteo di Giovanni of Siena in 1468.61

We are usually told, if we are told anything, the subject of a painting or a monument: the statue of Oceanus and Thetis, the story of St Lawrence or the three Magi. Razzi gives us the only description of a painting, the one that had allegedly spoken to St Thomas Aquinas. But nowhere is there an observation about composition, contour, design, or colour: all we can expect to know is that a work had been skilfully done.

The travellers did, however, take occasional notice of iconography, as when Gadenstedt remarks that the wolf and the sheep eating out of one bowl stand for justice. ${ }^{62}$ And there is a definite sensitivity for expression, as when Razzi tells us that the painting of the "Innocenti" just mentioned, expresses "molto ben gli affetti, crudeli e dogliosi de quel mistero." 63 Moryson, similarly, was so deeply impressed by the lively and artistic representation of the monuments of Ferdinand I and Alfonso II that he thought he had fallen among living princes, not dead images. ${ }^{64}$ Razzi is also the only traveller who expresses an awareness of style, when he says the figures are painted "alla antica." 65 But we must not forget that Razzi was, after all, an Italian from Florence, and probably more aware of artistic styles than the Northeners.

In the sixteenth century, Naples was not, then, a leading centre of the arts, 
although considerable work was undertaken in this century to better the general conditions of housing and public amenities. These works improved the city in many respects, not least aesthetically.

The first half of the century is marked by the relatively long reign of the Viceroy Don Pietro di Toledo (1532-53). He entered the town on September 4,1532 , and immediately with much energy and draconian laws initiated a programme of improvement. The town walls were rebuilt and enlarged, and the Castel S. Elmo was reconstructed (1537-46) and better fortified. Also restored and enlarged was the Castel Nuovo, in whose proximity the new viceregal palace was erected. From it the new main street was laid out, the so-called Via Toledo, following partly the old Aragonese wall. Along one side of this street, Toledo had erected on a chequered pattern the "quartieri spagnuoli" to house the troops. The Via Chiaia was also built and the principal streets were paved. The Viceroy issued an order to remove all the stands, stalls and other temporary structures in public streets and squares, which gave the city a disorganized, ugly, and dirty look. To improve the water supply to the city, he restored the Roman aqueduct and the old "ponte-canale" and had numerous public fountains constructed. ${ }^{66}$ Most of these improvements, as we have seen, were remarked upon by our travellers.

Due to the weakness of the viceroys following Don Pietro di Toledo, the second half of the century is marked by the undisciplined and chaotic expansion of the city. Corruption at all levels of the administration led to uncontrolled speculation in real estate on the one hand and to an immense increase of ecclesiastical properties on the other. ${ }^{67}$

But this slow undermining of the structural foundations of the city was not so easily recognised by travellers who stayed only a few days in the town. That in the latter half of the century they tended to mention more churches is significant in two ways. First, it reflects the increased ecclesiastical building activity in the city at the time. Second, it marks the beginning of the wave of general interest in the arts that was to increase over the coming centuries.

What is difficult for the modern traveller to comprehend is that for hundreds of years Naples was considered as one of the most beautiful cities - perhaps the most beautiful - in Italy. How much the travellers were attracted by its striking situation, its surrounding landscape, and its antiquities is shown by the appearance as early as 1539 of Benedetto Di Falco's "Descrittione dei luoghi antichi di Napoli e del suo amenissimo distretto."68

And the attraction of Naples continued without interruption. The rise of the abundant, rich and colourful Neapolitan Baroque overwhelmed later 
travellers. The arrival of the Farnese Collection was much discussed, interest in antiquity rose to new heights with the excavation of Herculaneum and Pompeii, and the mid-eighteenth-century development of interest in the beauty of nature and the discovery of the sublime and picturesque offered travellers even more reason to visit Naples.

\section{Ottawa}

\section{Notes}

1 More information on most of the travellers and the importance or influence of their accounts can be found in the comprehensive study on travel literature by Ludwig Schudt, Italienreisen im 17. und 18. Jahrhundert (Wien-München: Schroll-Verlag, 1959).

2 Discours viatiques de Paris d Rome et de Rome d Naples et Sicile (1588-1589), edition critique, introduction et notes de Luigi Monga, bibliotheca del viaggio in Italia, No. 15. (Geneva: Slatkine, 1983). This edition came to my attention only after I had finished this article, but the review of the book in Renaissance and Reformation, 22 (1986), 311-12, by Konrad Eisenbichler does not suggest that the statements on Naples and the arts are extensive or would disagree with other travellers' observations.

3 Fynes Moryson, An itinerary written by Fines Moryson gent. first in the Latine tongue, and then translated by him into English: containing his ten yeeres trauell through the twelue dominions of Germany, Bohmerland, Swizzerland, Netherland, Denmarke, Poland, Italy, Turky, France, England, Scotland, and Ireland. Diuded into II parts. The I. part containeth a journal through all the said twelue dominions... The II. part containeth the rebellion of Hugh, earle of Tyrone, and the appeasing thereof: written also in forme of a journall, The III. part containeth a discourse upon seueral heads, through all the said seuerall dominions (London: J. Baele, 1617).

Fynes Moryson (1566-1629) was a young jurist and fellow of Peterhouse in Cambridge. In 1591 at the age of 25, he left England and travelled for four years through many European countries and to Palestine and Turkey.

4 Moryson, pp. 103, 121.

5 Samuel Kiechel von Kiechelsberg, Die Reisen des Samuel Kiechel aus drei Handschriften, ed. K.D. Haszler (Stuttgart: Bibliothek des lit. Vereins zu Stuttgart, 1866), pp. 176, 177, 221.

Samuel Kiechel (1563-1619) came from a prosperous merchant family in the Swabian city of Ulm. He could afford to travel extensively for four years (1585-89) through many parts of Europe and the Ottoman Empire. Although information strictly concerning the arts is scarce in his account, he gives a lively view of the social life in Naples by describing the Carnival, a wedding banquet of the noble family Colonna, the celebration of Corpus Christi, and a fireworks display.

6 Sir Thomas Hoby, The travel and life of Sir Thomas Hoby, $K^{\prime}$ of Bisham Abbey, written by himself, 1547 - 1564, Edited for the Royal Historical Society by Edgar Powell (London: Offices of the Society, 1902).

Sir Thomas Hoby (1530-1566) is best known for his translation of Baldassare

Castiglione's book "Il Cortegiano." In 1545, at the age of fifteen, he began his studies at Cambridge, and in 1547 he left for the Continent to study and travel extensively. In 1550 he returned to England to take up a diplomatic career. He died in Paris at the age of 36 as ambassador at the Court of Henry II.

7 Hoby, p. 43.

8 See notes 5,12 , and 38 .

9 Hoby, p. 28.

10 Jerome Turler, The traueiler of Jerome Turler, deuided into two bookes. The first conteining a 


\section{8 / Renaissance and Reformation}

notable discourse of the maner, and onder of traveiling ouersea, or into strange and foreign countreys. The second comprehending an excellent description of the...realme of Naples in Italy (Imprinted at London by William How, for Abraham Veale, 1575). Book IL, pp. 166-69.

Hieronymus Turler (1550-1602) was a jurist and mayor of Leisnig, Saxony. His book was originally published in Latin in 1574 and appeared a year later in an English version.

11 Hoby, p. 31.

12 Barthold von Gadenstedt, Reisebeschreibung n. d. MS. (Herzog August Bibliothek Wolfenbuttel: Cod.-Guelf. 67.6 Extravatantium fol.). The manuscript has never been published, but there is a condensation by Karl Steinacker, Barthold von Gadenstedt's Italienreise 1587-89: Ostfalische Kulturbeziehungen zu Italien im 16. Jahrhundert (Braunschweig: E. Appelhans \& Co., 1941).

Barthold von Gadenstedt (1560-1632) was a dramatist from Wernigerode, Germany. He studied in 1585 in Helmstadt and travelled from 1587 to 1589 in Italy.

13 Gadenstedt, p. 460.

14 Serafino Razzi, Viaggio in Abruzzo: Inedito del XVI, ed. Benedetto Carderi (L'Aquila: L.U. Japadre, 1968), pp. 189-212.

Serafino Razzi (1531-1611) was an Italian friar of the Dominican house of S. Marco in Florence. After studying philosophy and theology, he occupied various positions during his long life as the prior of several convents, a professor, a gifted preacher, and, above all, a tireless writer. In 1577 he travelled to Naples.

15 Razzi, p. 196.

16 Johann Fichard, "Italia. Anno MDXXXVI. Autore Joanne Fichardo Jura C.," in Frankfurtisches Archiv f. altere deutsche Literatur und Geschichte, Vol. III. 1815, pp. 1-130.

Johann Fichard (1512-1581) is the earliest of the eleven travellers with whom we deal. He came to Naples in 1537. After studying law and humanities in Heidelberg, Freiburg, and Basel, he was summoned in 1536 to the Imperial Camp for military service in Northern Italy. He subsequently travelled throughout the peninsula.

17 Fichard, p. 79.

18 Turler, p. 179.

19 Fichard, p. 76.

20 Turler, p. 172.

21 Moryson, p.110

22 Moryson, p. 112.

23 Hoby, p. 28.

24 Gadenstedt, p. 465.

25 Moryson, p. 112.

26 Gadenstedt, p. 469.

27 Arnold Buchellius, "Iter italicum," ed. R. Lanciani in Archivio della $R$. Societa Romand di storia patria, 23. 1900, pp. 5-66; 24. 1901, pp. 49-93; 25. 1902, pp. 103-135.

Arnold von Buchell (Arnoldus Buchellius, 1565-1645) studied law and literature in Leiden. Before finally completing his education there in 1593, he travelled and studied in France, Germany, and Italy.

28 Buchellius, p. 119.

29 Turler, p. 173.

30 Fichard, p. 76.

31 Gadenstedt p. 467.

32 Gadenstedt, p. 459. 
33 Fichard, p. 77.

34 Codex Pighianus (Ms. lat. $2^{\circ}, 61$ ), Staatsbibliothek der Stiftung Preussischer Kulturbesitz Berlin.

Henning Wrede/Richard Harprath, Der Codex Coburgensis: Das erste systematische Archøologiebuch. Römische Antiken-Nachzeichnungen aus der Mitte des 16. Jahrhunderts, exhibition catalogue, Kunstsammlungen der Veste Coburg, Coburger Landesstiftung 7.9.2.11.1986.

35 Stephanus Vinandus Pighius, Hercules Prodicius, seu principis iuventutis vita et peregrinatio (Antwerpiae: C. Platinus, 1587).

Stephen Pigge (Stephanus Vinandus Pighius, 1520-1604), a classical scholar and archeologist from the Netherlands, studied in Louvain. From 1547 to 1555 he stayed in Italy, mainly in Rome as a protégé of Cardinal Marcello Cervini, who was then the head of the Vatican Library. In 1553 he visited Naples. For 14 years he served as secretary and librarian to Cardinal Granvelle in Brussels. In 1575 he returned to Italy as travel companion of Prince Karl Friedrich von Julich Cleve.

36 Pighius, p. 463.

Paul Hentzner, Itinerarium Germaniae, Angliae, Italiae cum indice locorum, rerum atque verborum commemorabilium huic libro accessere nova hâc editione (Leipzig: $\mathrm{H}$. Schürerianus \& M. Gơtzius, 1661), p. 466.

Paul Hentzner, a jurist, came to Italy as the travel companion of Dukes Johann Christian, Heinrich Wenzeslaus, and Karl Ferdinand of Silesia in May 1559.

37 Gadenstedt, p. 463.

38 Duke August the Younger of Braunschweig-Wolfenbuttel, Ephemerides sive Diarium n.d. MS. (Herzog August Bibliothek Wolfenbüttel: Cod.-Guelf. 42.19 Aug. 2\%), p. 19.

Duke August the Younger of Braunschweig-Wolfenbuittel (1579-1666) studied in Rostock and Tubingen. In 1598-1600 he travelled to Italy, Sicily, Malta, France, and England. The Duke was one of the most learned princes of his time, and his book collection formed the basis of the famous Wolfenbuttel Library.

39 Gadenstedt, p. 458.

40 Turler, pp. 174-76. Moryson has similar thoughts, p. 111.

41 Gadenstedt, pp. 448, 449.

42 Razzi, p. 202.

43 Richard Lassels, The voyage of Italy, or a compleat journey through Italy. In two parts. With the characters of the people, and the description of the chief towns, churches, monasteries, tombs libraries, pallaces, villas, gardens, pictures, statues and antiquities. As also of the interest, governement, riches, force, \&c. of all the princes. With instructions concerning travel. By RL., Gent. who travelled through Italy five times as tutor to several of the english nobility and gentry. Never before extant (Paris/London: John Starkey, 1670), part 2, p. 276.

44 Razzi, p. 202.

45 Moryson, p. 110.

46 Razzi, pp. 204, 205.

47 Gadenstedt, p. 446 . Hentzner, p. 457.

48 Gadenstedt, p. 446.

49 Gadenstedt, p. 447.

50 Gadenstedt, p. 451.

51 Fichard, p. 76.

52 Roberto Pane, "Guido Mazzoni e la pietà di Monteoliveto," in: Napoli Nobilissima, vol. XI, IV-VI, (Luglio-Dicembre 1972), pp. 49-69. 


\section{0 / Renaissance and Reformation}

53 Gadenstedt, p. 450.

54 Moryson, p. 110.

55 Razzi, p. 198.

Et a giudicio mio questo è il piu bel convento, il più ordinato, et il più commodo che abbia oggi l'Ordine nostro in Napoli. La chiesa e bella. Due sono i chiostri principali, in uno de $\mathrm{i}$ quali verdeggiano d'ogni tempo intorno a cinquanta aranci. I dormitori co' forse 60 celle sono in volta, et a crociera sopra, e sotto, e bellissimi.

La libreria tiene 40 banchi, ciod venti per banda, e tutti coperti di tele, e cortine azzurre accio la polvere no' guasti i libri: e le mura sono tutte dipinte di figure, a terra verde. Tieno questo magnifico convento per i forestieri da 12 in 16 camere reali, co' finestre invetriate con loggie ariose, e con pavimenti nobili. L'ospizio e la infermeria sono commode, e bene intese stanze. Et il lavatorio ha le pile tutte di candido marmo.

56 Fichard, p. 80; Turler, pp. 179, 180; Pighius, p. 451; Gadenstedt, p. 461.

57 Kiechel, p. 175.

58 Fichard, p. 76.

59 Gadenstedt, p. 458.

60 Razzi, p. 198.

61 Razzi, p. 198.

62 Gadenstedt, p. 458.

63 Razzi, pp. 198, 199.

64 See above n. 54.

65 See above $n .46$.

66 Roberto e Silvana di Stefano, "Il potere e lo spazio nella Napoli cinquecentesca," in Napoli nel cinquecento e la Toscana dei Medici (Napoli: Edizioni Scientifiche Italiane, 1980), pp. 82-91.

67 Di Stefano, pp. 174-76.

68 Benedetto Di Falco, Descrittione dei luoghi antichi di Napoli e del suo amenissimo distretto (Napoli: J. P. Sugganappo, 1539). 